\title{
Outdoor residential landscape design in an arid natural conservation area: Bahía de Los Ángeles, México
}

\author{
R. Rojas-Caldelas, G. Bojórquez-Morales, A. Luna-León, \\ E. Corona-Zambrano \& J. Ochoa-Corrales \\ Faculty of Architecture, \\ Universidad Autónoma de Baja California, México
}

\begin{abstract}
The designing of outdoor residential landscapes in a natural conservation area becomes crucial due to the restrictive use of natural resources, disturbance of habitat, and visual impact of man-made buildings. Therefore to integrate architecture and landscape design and to promote a better environment becomes a challenge. This is the reason why this paper focuses on the contributions of landscape design of outdoors in order to achieve sustainable architecture. This project is set in a small coastal rural village known as Bahia de Los Ángeles, municipality of Ensenada in the Mexican state of Baja California, which is located in the Flora and Fauna Natural Conservation Area of Valle de los Cirios, in the Sonoran Desert. Project development deals with four areas of environmental design of the outdoors in arid places: Firstly, the modification of micro climatic conditions. Secondly, the protection of ecological landscape features. Thirdly, the assessment of aesthetic and cultural values of arid landscapes and indigenous flora. Fourthly, the utilization of natural materials for landscaping. Lastly, some conclusions are set confronting the aesthetic and ecological values of deserts against preference of other ecosystems, as well as cultural and economic obstacles faced by sustainable development of rural housing projects.

Keywords: sustainable landscape design, landscape architecture, desert garden design, participative landscape design, arid landscape values.
\end{abstract}




\section{Introduction}

Doing sustainable housing projects is not new. There are numerous examples reported in practice as well as in literature. The same can be said with sustainable resource management on issues like water, energy, vegetation, landscape and solid waste among others. Most of the projects are mainly experimental or isolated and work under controlled environments or conditions, but then, a question arises: Is major audience acceptance missing? It could be that many people, theoretically, are in favour of sustainable development and think of it as a good idea for the environment and future generations; however, not all agree that it is a way of life for the present. Unfortunately our society has been conquered by spending and comfort patterns offered by the free market economy, and not many people are able to change.

Sustainable development and sustainable architecture remain then as an alternative approach, among others, for making projects. What we are sure of, is that there is a good foundation to build this way to sustainability supported by laws, construction codes, and public policies oriented to make a more efficient use of resources and to develop more friendly environmental technologies. This is what we have found in the housing project for single family household in a rural area in Baja California. Sustainable projects have many obstacles to surpass from the point of view of social acceptance, availability of financial resources for construction and maintenance, ecological constraints on the use of natural resources for building and to merge all of them in a specific time period. Sustainable development also implies an ample competence on various subjects, one of them being the integration of a group of experts that do not necessarily share the same sustainable development framework. So the challenge focuses on a comprehensive proposal capable to integrate sustainable principles in architecture and landscape architecture as a design problem.

Therefore this work has a double purpose in mind; on the one hand, to present a sustainable housing project where architecture and outdoor landscape design are integrated, underlying sustainable landscape design and, on the other, to assess the feasibility of sustainable development projects on wildlife protection areas like Valle de los Cirios in México.

In a broad sense, sustainable principles are the same when they are applied to landscape or architectural design. They deal with social, economic and ecological factors. Regarding social aspects, they are translated into social and cultural patterns of people, indoor and outdoor use of space, family and social values, aesthetic preferences, education levels, knowledge and management of technologies, interactions between man with the natural and man-made environment and participation in decision-making process. In the second aspect, economic factors are related to employment, income, cost of living, taxes and public or private financial resources for housing or productive programs. Regarding ecological factors, there are natural resources; implying inputs and outputs of materials, energy and information necessary to sustain man, plants and animals. So they provide us with resources for nourishment, clothing, medications, building materials and energy production, but their quality and 
quantity depend on their resilience. Resource management in both disciplines has tried to address several problems such as conservation on the long-term scenario or strategic approach; reduction, reuse and recycle of materials and energy within a system; and rational and efficient use of resources and the mitigation of environmental impacts.

\section{Methodology}

The housing project was designed keeping in mind that it is located in an extreme arid region, where it is crucial to manage scarce water resources, in aspects such as: temperature, wind, humidity, rainfall and underground water, as well as energy generation by solar and wind technologies. Another critical resource to preserve is biodiversity and landscape character, due to the fact that the site resides in a wildlife reserve containing ecosystems with high fragility index. The extraction of materials for building or mining is also restricted to certain places as well as the use of soft technologies. All of these shortcomings have demanded a project that mostly relies on the use of climatic passive principles for indoor and outdoor design spaces. Outdoor landscape design has also implied work over the concept of xeroscape Weinstein [1]. That is, centred in a wise management of available water resources, to promote the use of native plants to enhance biodiversity and the beauty of forms and colours of arid ecosystems. Native plants have suitable attributes compared to those induced plants; among them are their resistance to climatic stress, long periods of drought, high winds, control of soil erosion and their tolerance to salinity. The purpose of all of them is to reduce, reuse and recycle water, energy and materials, avoid disturbance of natural ecosystems and reduction of visual and aesthetic impacts over the landscape.

This paper underlines landscape contributions to architectural design in two stages: in the first one, it has been taken into account a description of regional landscape features to understand its physical nature and aesthetical values, as well as the essence to preserve its character, aspects that have been taken as inputs for outdoor design. In the second stage, there has been an interest to design a microenvironment around the house, considering the fundamentals of bioclimatic design and xeroscape. Achieving micro climatic adaptation of places has been done though the use of plants and other materials to provide shading over vertical and horizontal surfaces, as well as filtration or reduction of light over transitional places and wind management. Ecologically, a minimum removal of natural vegetation and topographic changes was proposed in order to preserve landscape features. Besides, native plants of the region for gardening were used and some of them were relocated on the terrain. Their use was thought to contribute towards minimizing water consumption and erosion. Aesthetically, spaces were designed integrating attributes such as: form, colour, texture, and diversity of plants; complementing the cultural preferences of the household in relation to scale and proportion of spaces, views, and significance of landscape marks. Natural elements, such as sand, gravel, pebbles, rocks, shells, and dead 
woods, were selected as materials for landscape purposes of pavement, fences, and partial shadings, depending on their availability in the region.

\section{Results}

Bahía de Los Ángeles is a small coastal town fig. 1with a population of about 698 inhabitants INEGI [2], located by the Sea of Cortez in Baja California, Mexico ( $28^{\circ} 55^{\prime}$ north latitude and $113^{\circ} 36^{\prime}$ west longitude). It also belongs to the Sonoran desert region and it is immersed in a flora and fauna wildlife reserve called Valle de los Cirios. The reserve is characterized by dominant and gigantic plant species: Pachycereus pringlei (Cardon) and Fouquieria columnaris (Cirio), and in addition, there are other 56 endemic plant species, 67 types of mammals, 86 types of birds and 52 types of snakes and lizards CONANP [3]. The climate has been considered among the hottest and driest places in the world, with an annual average rainfall of $40.4 \mathrm{~mm}$, with summer temperatures above $45^{\circ} \mathrm{C}$ and under $5^{\circ} \mathrm{C}$ in winter. Evapotranspiration varies annually from 600 to $1200 \mathrm{~mm}$. There are just a few watercourses, most of them are dry all year long, and main water sources are underground. In town, there is a spring with a limited capacity not enough to cater the needs of the population. In order to cover the deficit, water is brought by a pipeline coming from Agua Amarga, a subterranean reservoir located $30 \mathrm{~km}$ away. Water extraction is controlled by the National Water Commission CONANP-UABC [4]. Thus, water is a limitation to population growth and promotion of economic activities. However, there is always the chance to desalinate seawater to improve those conditions. The region has an enormous solar potential for energy production and a moderate one for wind. Actually, energy is partially provided by a diesel plant that works around 12 hours a day. Some people in town have solar panels to cover the daily deficit, but low-income households do not.

\subsection{Landscape assessment}

Sometimes in landscape assessment in wildlife areas, the ecological values are prioritized over cultural and aesthetic aspects, this project tries to establish a balance between those aspects. This is why; this section deals with the being-atthe-desert experience, as an important input for design. Valle de los Cirios is characterized by bare plains and gentle slopes; landscapes contrasting the blue, clean and bright skies; prevailing horizontal planes over vertical ones, and creating an atmosphere of infinite open space, unprotected, profound and distant from civilization. Vertical elements like hills and mountains have been developed as landmarks over the landscape, as well as green patches of desert trees and shrubs, showing the impact of dampness on the air or the existence of subterranean water. At plain sight, vegetation seems to be quite monotonous, mainly composed of small shrubs in shades of grey, usually with thorns and in low density; communicating the idea of dryness, thus, creating a distorted illusion associated to sensations of high temperatures and sandy soils. Contrary to this idea of poverty and lack of diversity, the desert has an outstanding beauty 
and a rich hidden world of living plants, animals and cultural heritage such as cave paintings that most of the time are not apparent at plain sight. Richness is present in small areas within great regions: in coastal beaches, small water springs, canyons, creeks and valleys, most of them are places of great biodiversity, where grasses, cactus and trees are the tallest. Colours, textures and forms are unusual and in a scale of monumental proportions. Therefore, deserts have a natural order and aesthetic values that have to be discovered and understood by foreigners in order to design and preserve the environment.

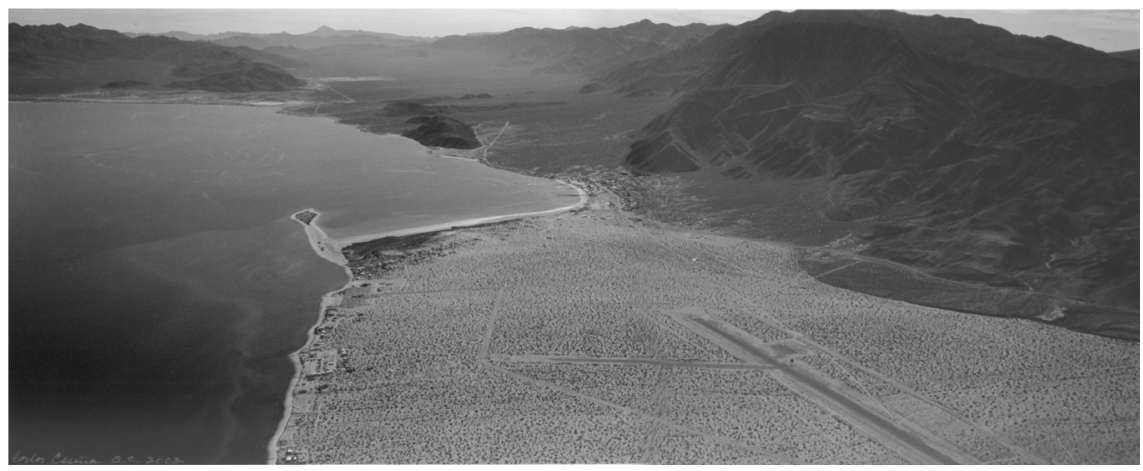

Figure 1: Aerial view of Bahía de Los Ángeles
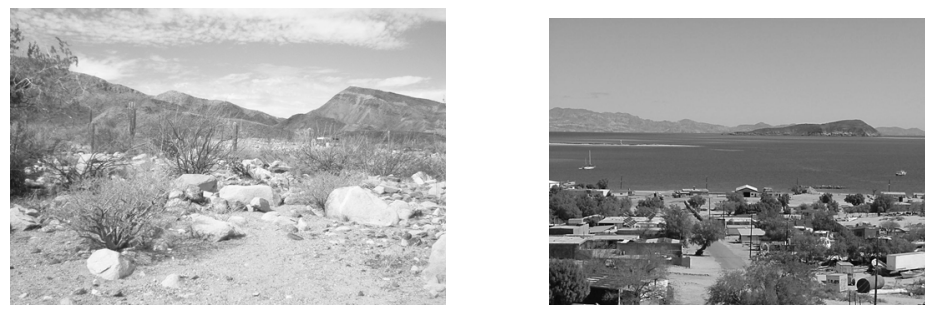

Figure 2: Site project and surrounding views to the mountains, sea and islands

\subsection{Site}

Bahía de Los Ángeles is a protected bay, surrounded by small mountain ridges, full of contrasts in colours and textures. The bay is a quiet and silent pond with great views to the islands of the Sea of Cortez fig. 2. The site is located over a moderate slope, full of big pieces of granite rocks, surrounded by two small creeks, streaming down from the top of the alluvial fan, limiting the North and South sides of the plot of land. Compared to other places in town, there are many desert plants and grasses like small size Pachycereus pringlei, Opuntia sp., Fouquieria peninsularis, Bursera microphylla, Lophocereus schotti, Cercidium microphyllum, Olneya tesota, Encelia farinosa, Ferocactus, Pedilanthus macrocarpus, Agave desertii, Larrea tridentata, Simondsia chinensis, Ambrosia dumosa INEGI [5] all of them useful for gardening. The natural conditions of 
the terrain have offered us resources for design. The project has been developed over terraces with nice views to the bay, mountains and islands. Creeks were preserved and integrated as natural borders of the plot of land in order to allow the water to flow down during the rainy season. In addition, some rocks were pilled to enclose the backyard and others were put in small groups making ornamental islands over the terrain.

\subsection{Household}

The household consists of a young couple with a dog and no children, and both are very concerned about preservation of the environment because their daily living depends on it. Roberto is a fisherman and usually goes sailing in the Sea of Cortez. Sometimes, he is hired as a tourist guide or by marine researchers, supporting them in reconnaissance surveys of whales, dolphins, whale sharks and sea turtles. Isabel is a biologist working for the Secretariat of Environment and Natural Resources in Bahía de Los Ángeles, where she is responsible of safeguarding natural resources of the islands of the Sea of Cortez. As we have seen, both share the same environmental interests and they are active people involved in many community activities to improve their own town. Their background was relevant to us because they were sensitive to accept the design of an alternative housing project, understanding that the construction would be progressive or in stages because of the lack of financial resources to do it in a short period of time. The land belongs to Roberto and they would like to have a house open to the views of the bay, mountains and islands, but at the same time they want to feel protected from the outside. Both have agreed to have native plants for gardening in order to satisfy aesthetic and medicinal values and the use of local materials. In addition, they would like to have a terrace in the upper floor for multiple uses such as a place to sleep outside in summer protected from any kind of animals, or as a place to rest or entertain friends and relatives. Roberto also needs a place where he can clean and fillet fish and a parking space for his pickup truck and the boat.

\subsection{Design criteria}

Outdoor design is going to have slight perimeter limits to allow visual contact with landscape, taking advantage of creeks, small size shrubs, fences and trees. There are two types of views to be promoted: close and distant, the first one has to be rich in forms, colours and textures. The second one has to capture natural landscapes from around the site. Transitional areas are designed as a way for passing from sunny to shaded spaces. Architectural design is going to be organized around a patio concept, taken from Mexican colonial houses. Architectural design is based on low energy passive strategies and the use of solar panels for water heating and energy production. Shades from volumes, man made shades and trees are also important in the provision of comfortable open spaces. Recycled water is going to be used for gardening. There will be a place to dispose organic waste. Criteria that has been applied in the housing project fig. 3,4 and table 1 . 


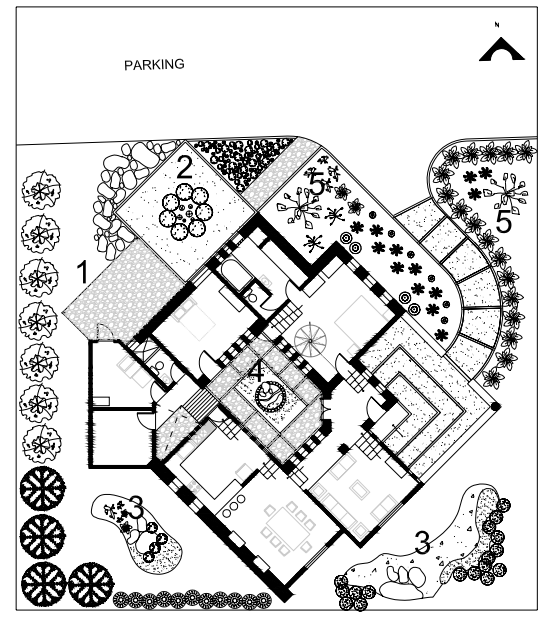

Figure 3: Garden layout; 1 backdoor entrance, 2 contemplative patio, 3 contemplative landscape views, 4 Indoor patio, 5 ornamental main entrance.

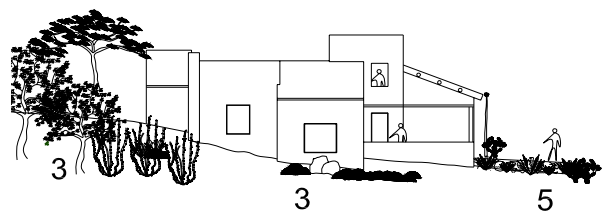

South-East Façade

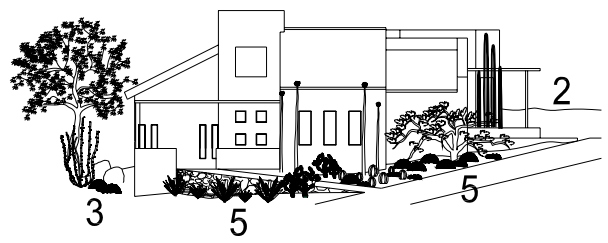

North-East Façade

Figure 4: Façades showing plant arrangement of landscape outdoors with native plants. 
Table 1: $\quad$ Environmental functions of landscape elements.

\begin{tabular}{|c|c|c|c|}
\hline $\begin{array}{l}\text { Space and } \\
\text { function }\end{array}$ & Vegetation & Pavements & $\begin{array}{l}\text { Furniture and } \\
\text { Utilities }\end{array}$ \\
\hline $\begin{array}{l}\text { 1. Patio } \\
\text { Back door entrance, } \\
\text { transitional space } \\
\text { for clothesline }\end{array}$ & & Pebbles & $\begin{array}{l}\text { Partial } \\
\text { horizontal } \\
\text { shading made } \\
\text { of cardon dead } \\
\text { woods } \\
\text { clothesline. }\end{array}$ \\
\hline $\begin{array}{l}\text { 2.Contemplative } \\
\text { patio from the } \\
\text { studio }\end{array}$ & $\begin{array}{l}\text { Creation of a microclimatic } \\
\text { space: shaded by trees over the } \\
\text { west façade: rich in textures, } \\
\text { forms and colours: Cercidium } \\
\text { microphyllum, Prosopis } \\
\text { glandulosa, Lophocereus } \\
\text { schotti Machaerocereus } \\
\text { gummosus, Simmondsia } \\
\text { chinensis, different cactus } \\
\text { species and rocks }\end{array}$ & $\begin{array}{l}\text { Wood and } \\
\text { compacted sand }\end{array}$ & $\begin{array}{l}\text { Rocks } \\
\text { Slope driven to } \\
\text { the centre of } \\
\text { space to } \\
\text { capture rainfall }\end{array}$ \\
\hline $\begin{array}{l}\text { 3. Contemplative } \\
\text { views from kitchen, } \\
\text { dinning and living } \\
\text { room }\end{array}$ & $\begin{array}{l}\text { Island arrangements made with } \\
\text { desert plants, rocks and annual } \\
\text { flowers (Abronia villosa, } \\
\text { Eschscholtzia mexicana, } \\
\text { Beloperone californica, } \\
\text { Encelia farinose). }\end{array}$ & $\begin{array}{l}\text { Specific spots of } \\
\text { sand, gravel and } \\
\text { wood }\end{array}$ & $\begin{array}{l}\text { Slope driven to } \\
\text { the centre of } \\
\text { the plot to } \\
\text { capture rainfall }\end{array}$ \\
\hline $\begin{array}{l}\text { 4. Indoor patio: } \\
\text { Contemplative } \\
\text { Shaded } \\
\text { Ventilation } \\
\text { Natural lightning }\end{array}$ & & $\begin{array}{l}\text { Wood, squares of } \\
\text { pebbles and } \\
\text { compacted sand }\end{array}$ & $\begin{array}{l}\text { Small fountain } \\
\text { as a water } \\
\text { reservoir } \\
\text { Big size rocks } \\
\text { Recycled } \\
\text { water }\end{array}$ \\
\hline $\begin{array}{l}\text { 5. Main entrance, } \\
\text { ornamental }\end{array}$ & $\begin{array}{l}\text { One side is limited by a line of } \\
\text { Agave desertii, Opuntia } \\
\text { violacea, Opuntia cholla. and } \\
\text { Burcera microphyla. On the } \\
\text { other side Burcera microphyla, } \\
\text { Fouquieria columnaris and } \\
\text { splendens, Pachycereus } \\
\text { pringlei, Opuntia fulgida, } \\
\text { Opuntia englemanni, } \\
\text { Pedilanthus macrocarpus and } \\
\text { different cactus species }\end{array}$ & $\begin{array}{l}\text { Pathway to the } \\
\text { entrance, sand and } \\
\text { wood. }\end{array}$ & $\begin{array}{l}\text { Recycled } \\
\text { water and } \\
\text { Slope driven to } \\
\text { the centre of } \\
\text { space to } \\
\text { capture rainfall }\end{array}$ \\
\hline $\begin{array}{l}\text { Porch, transitional } \\
\text { space, as an outside } \\
\text { living room in } \\
\text { summer }\end{array}$ & & $\begin{array}{l}\text { Partial horizontal } \\
\text { shading made of } \\
\text { cardon dead woods } \\
\text { Small walls made of } \\
\text { sand sacs plastered } \\
\text { with cement and } \\
\text { some outdoor } \\
\text { furniture or a } \\
\text { hammock. }\end{array}$ & $\begin{array}{l}\text { Compacted } \\
\text { sand and wood }\end{array}$ \\
\hline $\begin{array}{l}\text { Parking space for } \\
\text { the pickup truck } \\
\text { and the boat }\end{array}$ & $\begin{array}{l}\text { Perimetral fence made of } \\
\text { living sticks of Fouquieria } \\
\text { splendens }\end{array}$ & $\begin{array}{l}\text { Partial horizontal } \\
\text { shading made of } \\
\text { cardon dead wood }\end{array}$ & $\begin{array}{l}\text { Levelled and } \\
\text { compacted soil }\end{array}$ \\
\hline
\end{tabular}




\section{Discussion}

At the beginning of the project we were very enthusiastic trying to make a sustainable housing project and it was easy to do it on paper and maybe as experimental work; but our doubts began when someone asked us what could happen if a major demand of this prototype or any other in this community were requested. We would face the problem of environmental destruction, which would be critical in a natural protected area such as this one. That has made us think about other questions that need to be answered in order to promote sustainable buildings in this kind of areas:

1. People are conscious about the value of natural resources and cultural heritage for preservation purposes. They also look at sustainable development as a tool for improving their quality of life, but they disagree with the great amount of regulations and the high cost they represent, like permits and licences. That means that only wealthy households will be able to comply with the requirements.

2. Many people in Bahía de Los Ángeles agreed that sustainable development is a good thing for the environment and future generations, but they see this proposal far from their own reality because they are low income households, as the young couple that we have been working with.

3. Housing projects for low-income people in Mexico have to be seen as life projects to be built up in stages though a long period of time. Therefore, sustainable projects are not feasible for short term completion.

4. Wildlife protected areas have many regulations over the use of resources; in fact, it is easier to import technology, materials, and even labour force to build a project or to live in a mobile home like many retired Americans do. That has resulted in a negative visual impact, in creating pollution, and in a lack of identity with local architecture, culture, and landscape, instead of promoting endogenous development with ad hoc technologies, using local materials and labour force.

5. Sustainable houses will demand materials such as wood for building and shading; rocks, sand, gravel, insulation sheets, pipes, steel, and water reduction accessories; solar and wind technologies for energy production, water heating, water desalination, and water pumping accessories; safe disposal of batteries; specialized labour force; water treatment plants; and native plants production in nurseries for gardening. Therefore, it is necessary to promote the creation of "green enterprises" oriented to cater local needs to contribute to local development.

6. It is impossible to achieve comfort with passive design strategies in extreme climatic regions; thus it is necessary to use active systems for cooling. Natural landscapes are valuable resources for most of people and therefore they have a positive attitude towards them, such as forests, mountains, lakes, rivers, and beaches. However, for the layman, 
deserts are considered terrible places to visit because not everyone likes being hot, dry, full of dust, and might consider them dangerous and without trees. This is a negative cultural image that has been created over the years about deserts, when deserts are just simply different ecosystems with other aesthetical values.

\section{Conclusions}

Despite the fact that there are people able to put into practice sustainable development, there are short term obstacles, such as financial constraints and regulations. Therefore, sustainable projects have to be seen as projects with a series of stages to be completed in a long term plan.

When projects are designed integrally and in a collaborative way, they have better environmental responses, but this is not enough to get them to work. Sustainable development projects are much more than making a simple design because it implies deep changes in cultural patterns of spending, clean production, and the development of local community capacities and technology.

\section{References}

[1] Weinstein, Gayle (1999). Xeriscape handbook: a how-to guide to natural resource-wise gardening, Fulcrum Publishing, p 142.

[2] INEGI (2001). XII Censo de población y vivienda 2000, Instituto Nacional de Estadística, Geografía e Informática, México.

[3] CONANP (2003). Programa de Conservación y Manejo del Área de Protección de Flora y Fauna Valle de los Cirios, borrador de trabajo, http://www.conanp.gob.mx/anp/cirios/PCM_VC_270803A.doc

[4] CONANP-UABC (2004). Diseño participativo de una estrategia de desarrollo rural sustentable para la comunidad de Bahía de Los Ángeles, Baja California, México, informe técnico presentado a la Comisión Nacional de Áreas Naturales Protegidas-SEMARNAT, p. 182.

[5] INEGI (2001). Síntesis de Información Geográfica del Estado de Baja California, Instituto Nacional de Estadística, Geografía e Informática, México. 